\title{
Bacteriological Quality of some Meat Products in the Egyptian Retail
} Markets

\author{
Ragab, W.S. ${ }^{1}$; Ehsan A.B. Hassan² ${ }^{2}$ M.A. Al-Geddawy ${ }^{1}$ and A.A. Albie ${ }^{1}$ \\ ${ }^{1}$ Food Science and Technol. Dept., Faculty of Agriculture, Assiut University \\ ${ }^{2}$ Microbiology Department, Faculty of Medicin, Assiut University \\ Received on: 30 /8/2016 \\ Accepted for publication on: 6/9/2016
}

\begin{abstract}
This study was aimed to evaluate the bacteriological quality of some meat products produced by different companies in the Egyptian markets. 50 samples from five different sources of each of minced meat, beef burger, kofta, and sausage were subjected to bacteriological analysis. Isolation and identification of pathogenic and Public Health Hazard bacterial groups were carried out. The obtained results indicated that minced meat has the highest contamination level compared with the other products. The mean values of total bacterial count isolated from minced meat, kofta, beef burger and sausage samples were $6.6 \mathrm{x} 10^{8}$, $4.6 \times 10^{6}, 3.1 \times 10^{5}$ and $5.6 \times 10^{4} \mathrm{CFU} / \mathrm{g}$, respectively. Escherichia coli were detected in $50 \%$ of the examined minced meet samples and $30 \%$ of both kofta and beef burger but not found in sausage samples. Salmonella were isolated from 20 $\%$ of minced meat sample and $10 \%$ of Beef burger at levels of $6 \times 10^{4}$ and $4 \times 10^{2}$ $\mathrm{CFU} / \mathrm{g}$, respectively. Data also showed that $20 \%$ of minced meet samples and $10 \%$ of both kofta and beef burger samples were contaminated with Staphylococcus aureus at levels of $3 \times 10^{3}, 4 \times 10^{2}$ and $2 \times 10^{2} \mathrm{CFU} / \mathrm{g}$, respectively.
\end{abstract}

Keywords: Meet products, contamination, pathogenic bacteria.

\section{Introduction}

Meat is a very important food to human health due to its composition; Meat is rich in high quality protein, fats, vitamins, minerals and trace elements, so that a huge number of people consume meat and meat products. Generally, meats are very susceptible to quality loss due to microbiological spoilage. The bad and improper processing, handling and storage of meat products lead to spoilage which rises to economic losses and public health hazard.

Meat and meat product such as minced meat are appreciated because of its convenience. Unfortunately, their shelf- life is limited because the large exposed surface area facilitates spoilage. The rate of deteriorative change depends on meat composition, hygienic practices during cutting, grinding, and preparation, as well as storage conditions. The most important factor in controlling meat spoilage is microbial contamination and their growth, which affect safety and quality (Brooks et al., 2008). Food safety experts, agree that pathogen reduction requires a farm to the table approach. Microbiological testing is designed to address improvements at the plant level, with the understanding that additional initiatives at other points in the food production chain also are needed. USDA already has began a number of projects to address these other points, including safe handling instructions for consumers, identification and trace back of animals, and the development of onfarm pathogen prevention models. FSIS established a series of baseline data collection programs to acquire 
information that provides general microbiological profiles of meat and poultry for selected microorganisms that are of various degrees of public health concern (Mead, et al., 1999). Baseline studies are also used to develop pathogen reduction performance standards that plans must meet earlier baseline studies (steer/heifer, cow/bull, broiler chicken, market hog, and young turkey) and surveys (raw ground beef, raw ground chicken, and raw ground turkey) included the following microbial analyses of Escherichia coli; Clostridium perfringens; Staphylococcus aureus; Listeria monocytogenes; Campylobacter; Escherichia coli 0157:H7; and Salmonella (Friedman et al.,2002). Although the total bacterial count was used in bacteriological examination to reflect the hygienic quality, however, it is evident that coliform group count is considered of much greater value in assessing its quality (Djenane et al., 2011). Salmonella is now established, as one of the most important causes of food brone illness at worldwide (Hussien, 2006). The Staphylococcal genus contains at least 23 species, most important being Staphylococcus aureus. This organism is of major concern to the meat and poultry industries (Hannan et al., 2008).

The purpose of the study was to assess the bacteriological quality for retail packages of some meat products produced by different companies in the Egyptian market. Isolation and identification of some pathogenic and health hazard bacterial groups was carried out.

\section{Materials and Methods}

Samples of meat products:

Two hundred retail package samples of minced meat, beef burger, kofta, and sausage (50 samples of each product collected from five different sources - 10 samples of each source) were purchased from local market of Assiut City, Egypt.

Media used:

1-Media used for determination of total bacterial count:

Nutrient agar medium (American Public Health Association (A.P.H.A), 1976 and Difco manual, 1984) was used for the determination of total bacterial count.

2-Media used for isolation of Staphylococcus aureus:

Manitol salt agar media and Vogel Jonson media were used to isolate Staphylococcus aureus according to Difco manual,(1984).

3-Media used for isolation of coliform group bacteria:

Mac Conkey broth, Mac Conkey agar and Eosin methylene blue agar media were used for isolation and identification of coliform bacteria (E. coli) according to Difco manual, (1984).

4-Media used for isolation Salmonella:

The salmonella - shigella - agar medium was used as selective plating medium as described by (FAO, 1979).

Preparation of samples for bacteriological analysis:

Ten grams of each sample were mixed with $90 \mathrm{ml}$ of sterile saline solution $(9 \mathrm{~g} \mathrm{Na} \mathrm{Cl} / 1 \mathrm{~L}$ distilled water) under sterile conditions to give $1 / 10$ dilution. Serial dilutions were prepared to be used for counting several types of bacteria.

\section{Determination of total bacterial count:}

The total bacterial count was determined using the plate counts technique on a nutrient agar medium according to procedures of A.P.H.A (1976) and Difco manual, (1984). 
The plates were incubated at $37^{\circ} \mathrm{C}$ for $48 \mathrm{hrs}$.

\section{Isolation of Staphylococcus aureus:}

Staphylococcus aureus bacteria was determined according to the method described by (A.P.H.A., 1976 and Difco manual, 1984) using Vogel Jonson medium plus $1 \mathrm{ml}$ potassium tellurite solution $1 \%(\mathrm{w} / \mathrm{v})$ to each $100 \mathrm{ml}$ of sterilized medium which mixed well before pouring in the plates. The plates were incubated at $37^{\circ} \mathrm{C}$ for $24 \mathrm{hr}$.

\section{Isolation of coliform bacteria:}

Coliform group bacteria were determined using Mac Conkey agar medium according to the procedures described by A.P.H.A (1976) and Difco manual, (1984). The plates were incubated at $37^{\circ} \mathrm{C}$ for $24 \mathrm{hr}$.

\section{Isolation of Salmonella:}

The presence or absence of Salmonella was determined according to the method described by FAO (1979). Salmonella - Shigella agar plates were incubated at $35^{\circ} \mathrm{C}$ for 24 hr. Salmonella appeared as black colonies, some of them with metalic sheet.

\section{Results and Discussion}

Data presented in Table (1) showed the total aerobic bacterial count isolated from minced meat, kofta, beef burger and sausage samples collected from different sources. The bacteriological analysis indicated that minced meat has the highest contamination level compared with the other products. The total count of aerobic bacteria isolated from minced meat ranged from $5 \times 10^{6}$ to $10 \times 10^{8}$ with an average of $6.6 \times 10^{8} \mathrm{CFU} / \mathrm{g}$. At the same time, the mean values of total bacterial count isolated from kofta, beef burger and sausage samples were $4.6 \times 10^{6}, 3.1 \times 10^{5}$ and $5.6 \mathrm{x}$ $10^{4} \mathrm{CFU} / \mathrm{g}$ respectively.

The obtained results are in agreement with those recorded by Mousa et al. (1993), They investigated microbial quality of 50 samples of luncheon and minced meat (25 samples of each). They showed that the minced meat has heavier bacterial load than luncheon samples and they traced this result to miss handling, improper hygienic measures during manufacturing and transportation and keeping methods as well as methods of exposure to sale. Also, Tolba (1994) examined 80 samples of minced meat, kofta, beef burger and luncheon (20 samples each) from different areas in Cairo and Giza. They found the aerobic plate counts for these previous products were $2.2 \mathrm{x}$ $10^{6}, 2.9 \times 10^{3}, 2 \times 10^{5}$ and $1.3 \times 10^{5}$, respectively.

Doyle et al., (2007) reported that fresh minced meat tends to have a short shelf life because the quality of the raw ingredients is usually lower (i.e., has higher number of contaminating microorganisms), and is re-contaminated through the grinding /handling process. Mincing and grinding of meat at the retail location can introduce more spoilage microorganisms if proper equipment hygiene and handling measures are not followed. 
Table 1. Total aerobic bacterial count (CFU/g) of meat products samples

\begin{tabular}{|c|c|c|c|c|c|c|}
\hline \multirow{2}{*}{ Meat Products } & \multirow{2}{*}{$\begin{array}{c}\text { No. of } \\
\text { samples }\end{array}$} & \multicolumn{2}{|c|}{ Positive samples } & \multicolumn{3}{|c|}{ Aerobic bacterial Count (CFU/g) } \\
\cline { 3 - 7 } & 50 & 50 & $100 \%$ & $5 \times 10^{6}$ & $10 \times 10^{8}$ & $6.6 \times 10^{8}$ \\
\hline Minced meat & 50 & 50 & $100 \%$ & $5 \times 10^{4}$ & $5 \times 10^{6}$ & $4.6 \times 10^{6}$ \\
\hline kofta & 50 & 50 & $100 \%$ & $3 \times 10^{4}$ & $6 \times 10^{5}$ & $3.1 \times 10^{5}$ \\
\hline Beef burger & 50 & 50 & $100 \%$ & $3 \times 10^{3}$ & $8 \times 10^{4}$ & $5.6 \times 10^{4}$ \\
\hline Sausage & 50 & \multicolumn{4}{|c}{}
\end{tabular}

Data in Table (2) showed that $E$. coli was detected in $50 \%$ of the examined minced meet samples and $30 \%$ of both kofta and beef burger samples. The average values of the contamination level with $E$. coli were $6 \times 10^{4}, 6 \times 10^{2}$ and $4 \times 10^{2}$ in the examined samples of minced meet, kofta and beef burger, respectively.
On the other hand, E.coli couldn't detect in the examined sausage samples. Nearly similar results were found by previous investigators. Duitschaever (1977) and Fathi et al., (1992), they detected E.coli in $47.37 \%$ and $28.3 \%$ of the examined minced meat and beef burger samples.

Table 2. Escherichia coli count (CFU/g) in meat products samples

\begin{tabular}{|c|c|c|c|c|c|c|}
\hline \multirow{2}{*}{ Meat Products } & \multirow{2}{*}{$\begin{array}{c}\text { No. of } \\
\text { samples }\end{array}$} & $\begin{array}{c}\text { Positive sam- } \\
\text { ples }\end{array}$ & \multicolumn{3}{|c|}{ Escherichia coli count } \\
\cline { 3 - 7 } & & No. & $\%$ & Min. & Max. & Mean \\
\hline Minced meat & 50 & 25 & $50 \%$ & $3 \times 10^{2}$ & $8 \times 10^{4}$ & $6 \times 10^{4}$ \\
\hline kofta & 50 & 15 & $30 \%$ & $2 \times 10^{2}$ & $10 \times 10^{2}$ & $6 \times 10^{2}$ \\
\hline Sausage & 50 & 0 & 0 & - & - & - \\
\hline Beef burger & 50 & 15 & $30 \%$ & $1 \times 10^{2}$ & $6 \times 10^{2}$ & $4 \times 10^{2}$ \\
\hline
\end{tabular}

Fig. (1 and 2): Isolation of E. coli from meat products on Mac-Conkey agar and EMB agar media.

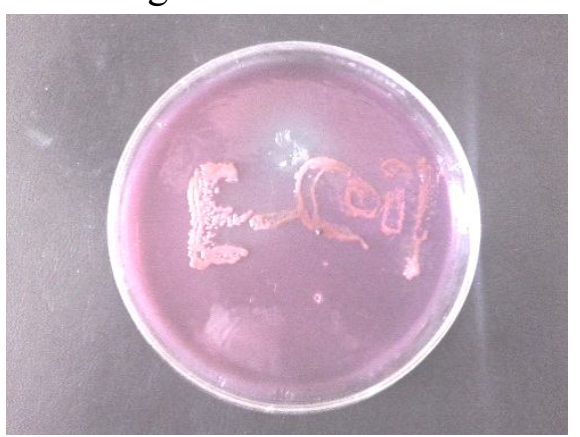

Fig. (1) : E-coli on Mac-Conkey agar give Pink colonies

Table (3) clears that the incidence of salmonella in miced meat and Beef burger samples were $20 \%$ and $10 \%$, respectively, but not detected in Sausage and kofta. Salmo-

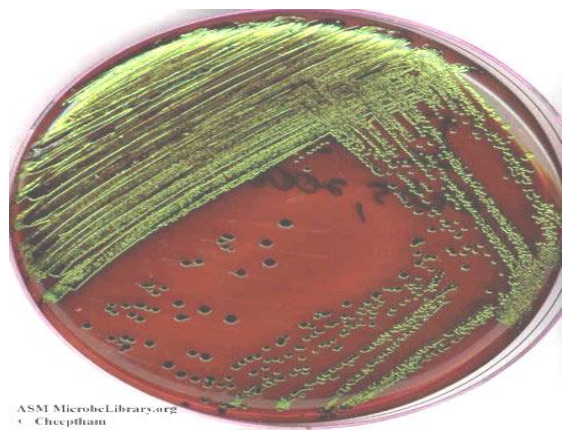

Fig. (2): E-coli on EMB gives green metal shine

nella counts ranged from $3 \times 10^{2}$ to $8 \mathrm{x}$ $10^{4}$ with mean value of $6 \times 10^{4} \mathrm{CFU} /$ $\mathrm{g}$ of minced meat, but only ranged from $1 \times 10^{2}$ to $6 \times 10^{2}$ with a mean value $4 \times 10^{2} \mathrm{CFU} / \mathrm{g}$ of Beef burger. 
The obtained results were similar to some extent with that reported by ElMossalami et al. (1989), they found that the incidence of Salmonella in beef burger was $6 \%$ out of 50 samples and in frozen minced meat was $6 \%$ out of 50 tested samples and in fresh minced meat the percentage was
$12 \%$. In contrary, they failed to isolate salmonella from any of examined luncheon samples. Salmonella species were detected in $5 \%$ of the examined minced meat samples, but not found in any of the examined luncheon samples. (Abdel-Aziz et al. 1996) or kofta samples (Kuplul and Oral, 2003).

Table 3. Salmonella counts (CFU/g) in meat products samples

\begin{tabular}{|c|c|c|c|c|c|c|}
\hline \multirow{2}{*}{ Meat Products } & \multirow{2}{*}{$\begin{array}{c}\text { No. of } \\
\text { samples }\end{array}$} & \multicolumn{2}{|c|}{$\begin{array}{c}\text { Positive } \\
\text { samples }\end{array}$} & \multicolumn{3}{|c|}{ Salmonella counts } \\
\cline { 3 - 7 } & & No. & $\%$ & Min. & Max. & Mean \\
\hline Minced meat & 50 & 10 & $20 \%$ & $3 \times 10^{2}$ & $8 \times 10^{4}$ & $6 \times 10^{4}$ \\
\hline Raw kofta & 50 & 0 & $0 \%$ & & & \\
\hline Sausage & 50 & 0 & $0 \%$ & & & \\
\hline Beef burger & 50 & 5 & $10 \%$ & $1 \times 10^{2}$ & $6 \times 10^{2}$ & $4 \times 10^{2}$ \\
\hline
\end{tabular}

Fig. (3 and 4): Isolation of Salmonella from meat products on Mac Conkey agar and Bismus sulphate agar media.

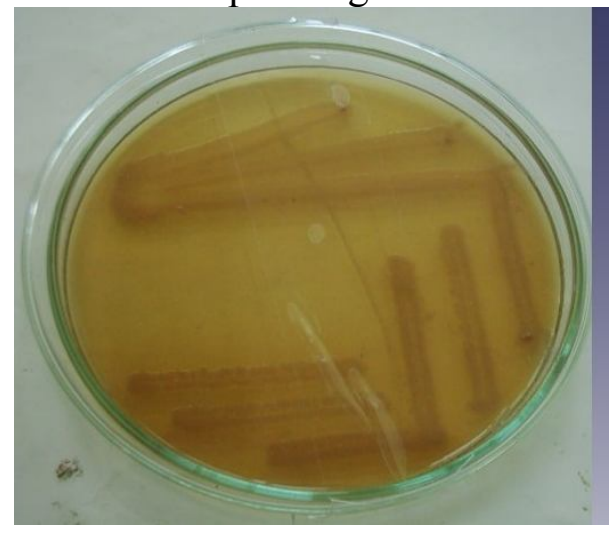

Fig.(3): pale yellow colonies of Salmonella on Mac. agar

Data presented in Table (4) indicated the incidence of Staphylococcus spp. in 10, 5, and 5 samples out of 50 analyzed samples of each of minced meat, kofta and beef burger but not in sausage samples. Minced meat showed the highest contamination level (3x $103 \mathrm{CFU} / \mathrm{g})$ Followed by beef burger (4x $102 \mathrm{CFU} / \mathrm{g})$ and finally kofta (2x $102 \mathrm{CFU} / \mathrm{g})$. Nearly similar results were obtained by

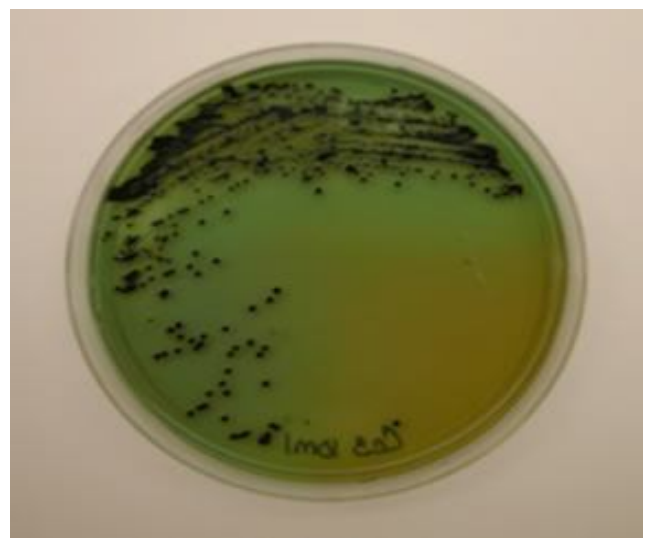

Fig.(4): black colonies of Salmonella on Bismus agar

Scanga et al. (1999) and Heredia et al. (2001) who detected Staphylococcus in $1.5 \%$ and $11.4 \%$ of the examined ground meat samples of the examined ground beef samples. On the other hand, Staphylococcus had not been detected in beef burger or minced meat as reported by Tolba (1994), Abdel-Aziz et al. (1996), Duffy et al. (1999), Chung et al. (2003). 
Table 4. Staphylococcus count (CFU/g) in meat product samples

\begin{tabular}{|c|c|c|c|c|c|c|}
\hline \multirow{2}{*}{ Meat Products } & \multirow{2}{*}{ No. of samples } & \multicolumn{3}{|c|}{ Positive samples } & \multicolumn{3}{|c|}{ Staphylococcus count } \\
\cline { 3 - 7 } & & No. & $\%$ & Min. & Max. & Mean \\
\hline Minced meat & 50 & 10 & $20 \%$ & $1 \times 10^{2}$ & $6 \times 10^{3}$ & $3 \times 10^{3}$ \\
\hline kofta & 50 & 5 & $10 \%$ & $1 \times 10$ & $4 \times 10^{2}$ & $2 \times 10^{2}$ \\
\hline Sausage & 50 & 0 & $0 \%$ & - & - & - \\
\hline Beef burger & 50 & 5 & $10 \%$ & $2 \times 10$ & $6 \times 10^{2}$ & $4 \times 10^{2}$ \\
\hline
\end{tabular}

Fig. (5 and 6): Isolation of Staphylococcus from minced meat samples on Mannitol salt agar and blood agar media

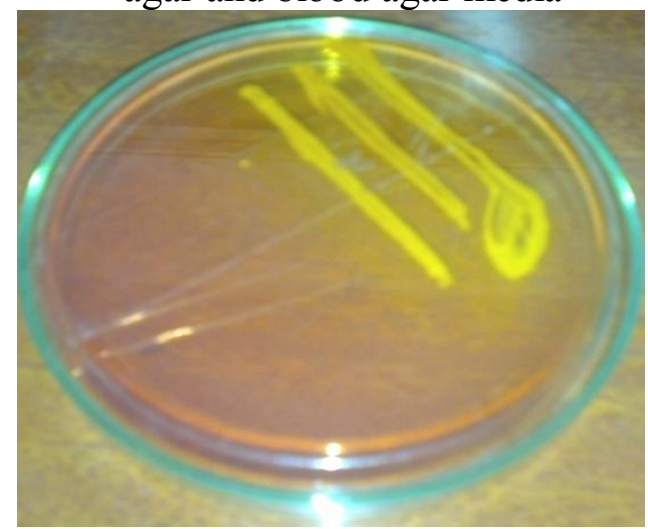

Fig.(5): yellow colonies of Staphylococcus on Mannitol salt agar pale

\section{Reference}

A.P. H. A. (1976). American public Healthy Association of Methods for the Microbiological Examination of Foods. Speck, M. L. ed., Washington, D. C., USA.

Abd-El-Aziz,A.S.,

Neklawy,E.,Hussien,A. and Niazi,Z. (1996). Food poisoning microorganisms in some local meat products. Vet. Med. J. Giza, 41(4)691698.

Brooks, J.; Alvarado, M.; Stephens, T.; Kellermeier, J.; Tittor, A. and Miller, M. (2008). Spoilage and safety characteristics of ground beef packaged in traditional and modified atmosphere packages. Journal of Food Protection, 71(2): 293-301.

Chung, Y.H., Kim, S.Y. and Chang.Y.H. (2003). Prevalence and antibiotic

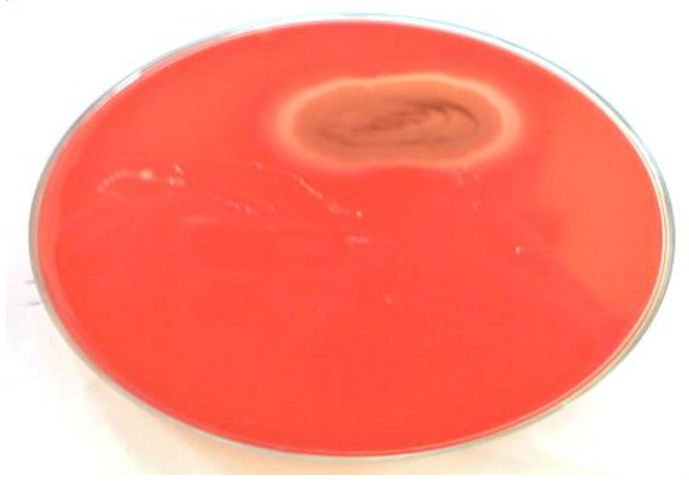

Fig.(6): B- haemolysis on blood agar with Clear zone around Staphylococcus colony

susceptibility of salmonella isolated from foods in Korea from 1993 to 2001. Journal of Food Protection, 66(7) :1154-1157.

Difco-Manual, (1984). Dehydrated culture media and reagents microbiological and clinical laboratory procedures, Pub-Difco-LabDetroits Michigan, USA.

Djenane, D.; Yangüela, J.; Amrouche, T.; Boubrit, S.; Bousaâd, N. and Roncalés, P. (2011). Chemical composition and antimicrobial effects of essential oils of Eucalyptus globulus, Myrtuscommunis and Saturejahortensis against Escherichia coli O157:H7 and Staphylococcus aureus in minced beef. Food Science and Technology, 22,1046-1053.

Doyle, M. P.; Beuchat, L. R. and Montville, T. J. (2007). Food Microbi- 
ology Fundamentals and Frontiers. Washington, DC: ASM Press.

Duitschaever, C.L. (1977). Bacteriological evaluation of some lunched meats in the Canadian Retail Market. Journal of Food Protection, 40(6):382-384.

Duffy,G.,Cloak,O.M.,Osullivan,M.G.,G uillet, A., Sheridan, J.J., Blair, I.S. and MeDowell, D.A. (1999). The incidence and antibiotic resistance profiles of salmonella spp. On Irish retail meat products. Food Microbiology, 16,623-631.

El- Mossalami, E.E., Safwat, E.E., AbdelAziz, Laiela, A.S. and E1Sawah, H.(1989). Salmonellae in locally produced meat products. J. Egypt Vet. Med. Ass., 49(1-2) 99108.

Fathi,S.M. and Rashwan, M.A.(1992). Coliform, Enterobacteriaceas and total aerobic mesophilic counts in some selected meat products. Assiut Vet. Med. J., 27(54):121-129.

FAO, (1979). Manuals of food-quality controls, 4, microbiological analysis. Food and Agriculture organization of the united nations. Rome, PP. C9-12 and DI-33.

Friedman, M.; Henika, P. R. and Mandrell, R. E. (2002). Bactericidal activities of plant essential oils and some of their isolated constituents against Campylobacter jejuni, Escherichia coli, Listeria monocytogenes, and Salmonella enterica. J. of Food Protection 65, 1545-1560.

Heredia, N., Garcia, S., Rojas, G. and Salazar, L.(2001). Microbiological condition of ground meat retailed in Monterrey, Mexico. Journal of Food Protection, 64(8) 1249-1251.

Hannan, A.; Sidrah, S.; Chaudhary, S.; Barkaat, M. and Arshad, M. U. (2008). Antibacterial activity of Nigella Sativa against clinical isolates of Methicillinresistant Staphylococcus aureus. J. of Ayub Medical College, Abbottabad, 20.

Hussien, S. M. (2006). Technological and biochemical studies on low fat meat products M. Sc. Thesis, Fac. of Agric., Minia Univ., Egypt

Küplül, O., Sarimehmetoglu, B. and Oral, N. (2003). The microbiological quality of Cig Kofta in Ankara. Turk. J. Vet. Anim. Sci,27:325329.

Mead, P.S.; Slutsker, L.; Detz, V.; McCaig, L.F.; Breese, J.S.; Shapiro, C.; Griffin, P.M. and Tauxe, R.V. (1999). Food related illness and dead in the United States. Emerging Infectious Diseases 5: 607-625

Mousa, M. M., Awad, H. A., Yassien, M.M. and Gouda,H.I.(1993). Microbial quality of some meat products. Vet. Med. J. Giza, 41(3): 5962.

Scanga, J.A., Bellinger, G.R., Belk, K.E. and Smith,G.C.(1999). Amicrobiogical profile of domestic and imported beef rawmaterials distended for use in ground beef production. Beef Program report, Department of Animal sciences, Colorado State University.

Tolba, K. (1994). Microflora in locally processed frozen meat, Vet. Med. J. Giza 42,(2): 99-105. 
الجودة البكتريولوجية لبعض منتجات اللحوم في أسواق التجزئة المصرية

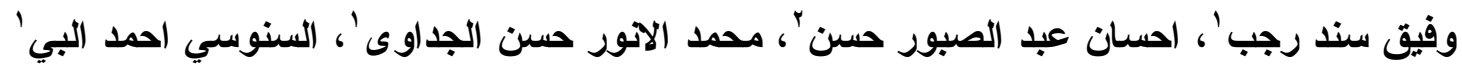

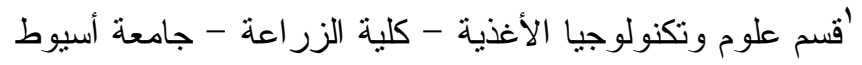

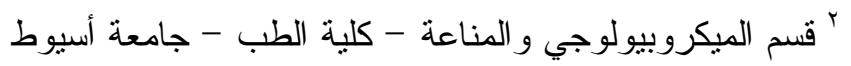

تهدف هذه الدراسة الي تقييم الجودة البكتريولوجية لبعض منتجات اللحوم المنتجة بواسطة

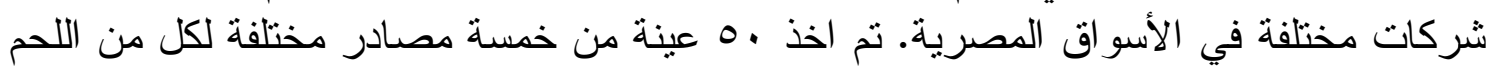

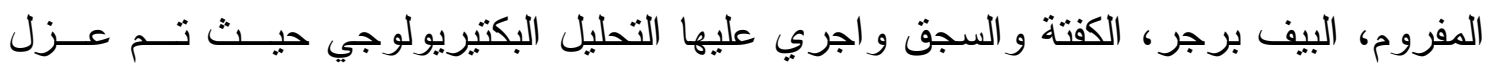

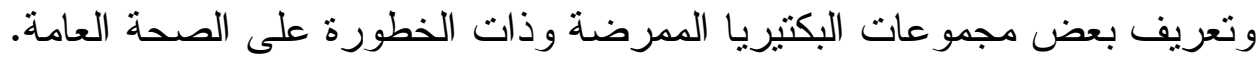

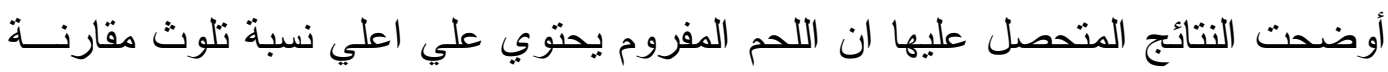

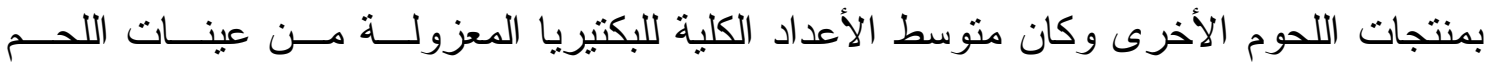

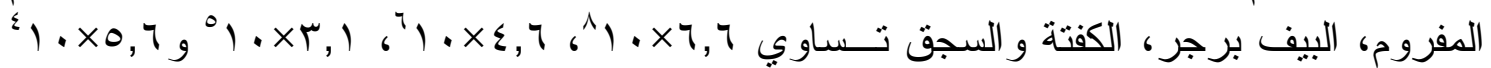

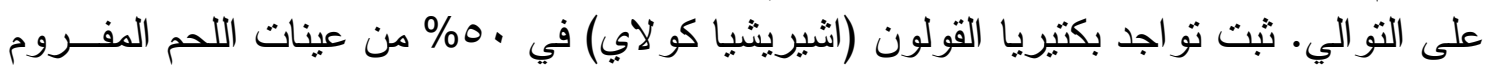

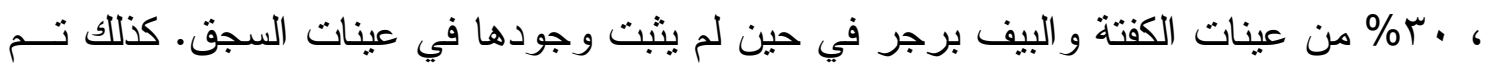

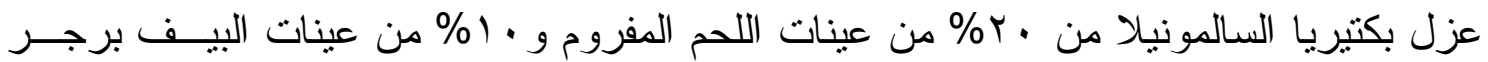

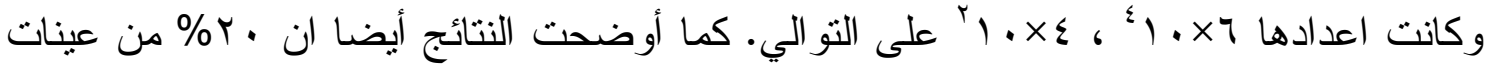

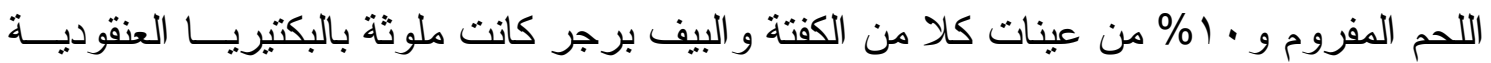

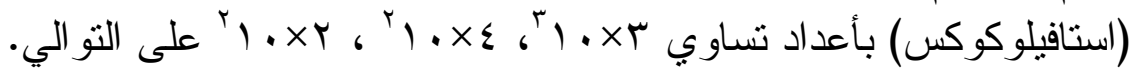

